\title{
DOI: $10.1038 / \mathrm{s} 41467-018-05359-2 \quad$ OPEN
}

\section{Publisher Correction: The origin and remolding of genomic islands of differentiation in the European sea bass}

\author{
Maud Duranton (10 1,2, François Allal (i) 2,3, Christelle Fraïsse ${ }^{1,2}$, Nicolas Bierne ${ }^{1,2}$, François Bonhomme ${ }^{1,2} \&$ \\ Pierre-Alexandre Gagnaire,2
}

Correction to: Nature Communications https://doi.org/10.1038/s41467-018-04963-6; published online 28 June 2018.

The originally published version of this Article contained errors in Fig. 5, whereby the sign for Spearman's rho was incorrect in panels $\mathrm{b}$ and $\mathrm{c}$. These errors have now been corrected in both the PDF and HTML versions of the Article.

Published online: 27 July 2018

\begin{abstract}
(c) Open Access This article is licensed under a Creative Commons Attribution 4.0 International License, which permits use, sharing, adaptation, distribution and reproduction in any medium or format, as long as you give appropriate credit to the original author(s) and the source, provide a link to the Creative Commons license, and indicate if changes were made. The images or other third party material in this article are included in the article's Creative Commons license, unless indicated otherwise in a credit line to the material. If material is not included in the article's Creative Commons license and your intended use is not permitted by statutory regulation or exceeds the permitted use, you will need to obtain permission directly from the copyright holder. To view a copy of this license, visit http://creativecommons.org/licenses/by/4.0/.
\end{abstract}

(C) The Author(s) 2018

\footnotetext{
${ }^{1}$ Institut des Sciences de l'Evolution de Montpellier - UMR5554 UM-CNRS-IRD-EPHE, Place Eugène Bataillon, 34095 Montpellier, France. ${ }^{2}$ Université de Montpellier, Place Eugène Bataillon, 34095 Montpellier, France. ${ }^{3}$ MARBEC, Université de Montpellier, Ifremer-CNRS-IRD-UM, 34250 Palavas-les-Flots,

France. Correspondence and requests for materials should be addressed to M.D.(email: maud.duranton@umontpellier.fr)
} 